OPEN ACCESS

Edited by:

Pedro Morais,

University of Algarve, Portugal

Reviewed by:

Niels Hintzen,

Wageningen Marine Research

IJmuiden, Netherlands

João Encarnação,

University of Algarve, Portugal

*Correspondence:

Pim G. Boute

pim.boute@wur.nl

tORCID:

Pim G. Boute

orcid.org/0000-0003-2954-635X

Maarten Soetaert

orcid.org/0000-0002-4073-5082

José A. Reid Navarro

orcid.org/0000-0001-8643-6603

Martin J. Lankheet

orcid.org/0000-0002-8261-2187

Specialty section:

This article was submitted to

Marine Biology,

a section of the journal

Frontiers in Marine Science

Received: 10 August 2020 Accepted: 10 December 2020

Published: 11 February 2021

Citation:

Boute PG, Soetaert M,

Reid Navarro JA and Lankheet MJ

(2021) Effects of Electrical Pulse

Stimulation on Behaviour and Survival

of Marine Benthic Invertebrates.

Front. Mar. Sci. 7:592650.

doi: 10.3389/fmars.2020.592650

\section{Effects of Electrical Pulse Stimulation on Behaviour and Survival of Marine Benthic Invertebrates}

\author{
Pim G. Boute ${ }^{1 * \dagger}$, Maarten Soetaert ${ }^{2 \dagger}$, José A. Reid Navarro ${ }^{1 \dagger}$ and Martin J. Lankheet ${ }^{1 \dagger}$ \\ ${ }^{1}$ Experimental Zoology Group, Department of Animal Sciences, Wageningen University \& Research, Wageningen, \\ Netherlands, ${ }^{2}$ Fisheries and Aquatic Production, Animal Sciences Unit, Institute for Agricultural, Fisheries and Food \\ Research, Ostend, Belgium
}

Electrical pulse trawling is an alternative to conventional beam trawling for common sole (Solea solea), with the potential for higher revenues and less impact on the marine ecosystem. Concerns exist, however, that benthic invertebrates might be seriously affected by pulse fishing. Even if direct injuries and mortality were limited, changes in behaviour might compromise their survival, with potentially large impacts on food webs. Here, we investigate effects of electrical pulses on locomotion behaviour and 14-days survival of six invertebrate species from four phyla that may encounter pulse fishing gears. Electrical stimulation consisted of a Pulsed Bipolar Current at $200 \mathrm{~V} \mathrm{~m}^{-1}$, $30 \mathrm{~Hz}, 0.33 \mathrm{~ms}$ pulse width, and $3 \mathrm{~s}$ duration. We quantified species-specific behaviours before, during, and after electrical stimulation and compared these to a non-exposed control group. Responses during stimulation varied from no visible effect (echinoderms) to squirming (sea mouse) and retractions (whelk and crustaceans). Within $30 \mathrm{~s}$ after stimulation, all animals resumed normal behavioural patterns, without signs of lasting immobilisation. Starfish, serpent star, whelk and sea mouse showed no change in movement patterns after stimulation, whereas flying crab and hermit crab showed significant changes in activity that were indicative of increased shelter behaviour. For none of the species, survival at 14-days after stimulation was negatively affected. These findings suggest that changes in locomotion behaviour due to electrical stimulation as used in pulse trawling are unlikely to substantially compromise survival of the investigated species.

Keywords: animal behaviour, benthic impact, bycatch species, electrical pulse fishing, locomotion activity, mortality, North Sea, righting reflex

\section{INTRODUCTION}

Bottom trawling for benthic species makes up a large proportion of global marine capture fisheries (Amoroso et al., 2018; Cashion et al., 2018; Watson and Tidd, 2018). Different types of bottom trawls have been developed depending on seabed habitats and target species (Watson et al., 2006; Eigaard et al., 2017). In northwestern European waters, beam trawls with tickler chains 
have conventionally been used to catch flatfish (Rijnsdorp et al., 2008; Lescrauwaet et al., 2013; Eigaard et al., 2016; van der Reijden et al., 2018). The mouth of the net is held open by a metal beam which is attached to two lateral 'shoes' that are pulled across the seabed, although fishermen nowadays may replace the beam and shoes by a hydrodynamic wing (Rijnsdorp et al., 2020a). To chase flatfish out of the sediment and into the following net, chains are transversally pulled through the seabed in front of the ground rope. This type of trawling is frequently criticised for poor selectivity (Kaiser and Spencer, 1995; Depestele et al., 2014; Bayse et al., 2016), for large disturbance of the benthic ecosystem (de Groot, 1984; Lindeboom and de Groot, 1998; Paschen et al., 2000; Kaiser et al., 2006; Depestele et al., 2016), and for high fuel consumption (Poos et al., 2013).

As an alternative to tickler chains for chasing fish from the seabed, fishermen targeting common sole (Solea solea) in the southern North Sea have introduced electrical pulse gears that can be installed on the same fishing vessels (Soetaert et al., 2015). These so-called pulse trawlers use pulsed electric fields to induce involuntary muscle contractions in the fish which chase them out of the sediment and immobilise them in front of the nets (Soetaert et al., 2019). The electrode arrays are dragged over the sediment in parallel with the towing direction and are typically towed at a lower speed than tickler chain gears (Rijnsdorp et al., 2020a). Pulse trawling is permitted under temporary derogations of the European Union's prohibition to catch marine organisms using electric current (Haasnoot et al., 2016; Soetaert et al., 2019). Compared to beam trawlers with tickler chains or chain mats (Rijnsdorp et al., 2008; Eigaard et al., 2016), pulse trawlers have several advantages, including increased selectivity (van Marlen et al., 2014; Poos et al., 2020) and discard survival (van der Reijden et al., 2017), and reduced seabed damage (Depestele et al., 2016, 2019; Tiano et al., 2019; Rijnsdorp et al., 2020a) and bycatch rates (van Marlen et al., 2014). Additionally, higher net revenues (Batsleer et al., 2016), resulting from higher catch efficiencies for sole (Poos et al., 2020) and 30-50\% lower fuel consumption (van Marlen et al., 2014; Poos et al., 2020), make pulse trawling a promising alternative with potentially less impact on the ecosystem.

Despite these advantages of pulse gear over tickler chains, concerns exist regarding possible negative impact of electrical stimulation on invertebrates (ICES, 2018; Quirijns et al., 2018). Electrotrawling for sole exposes benthic marine invertebrates to high electric field strengths near the electrode arrays (de Haan et al., 2016; de Haan and Burggraaf, 2018), which might compromise survival. Previous studies have shown that exposure to electrical pulses as used in electrotrawling for sole causes no, or very limited, internal injuries or direct mortality in marine benthic invertebrates (Smaal and Brummelhuis, 2005; van Marlen et al., 2009; Soetaert et al., 2014, 2016). However, as invertebrate species are generally not retained, indirect mortality may occur after a trawling event due to increased predation risk related to injuries or behavioural changes (e.g., Kaiser and Spencer, 1994; Evans et al., 1996; Collie et al., 2000; Chícharo et al., 2002). Increased mortality due to fishing efforts may disturb food web structures and hence indirectly affect the population dynamics of a wider range of species (e.g., Kaiser et al., 2002; Hiddink et al., 2011; van Denderen et al., 2013; Collie et al., 2017). It is unknown to what extent electrical stimulation affects invertebrate behaviour. Here, we especially investigate effects on locomotion behaviour, which could increase predation susceptibility after a trawling event (Murray et al., 2016), leading to indirect mortality.

Due to the large variety in neuromuscular and musculoskeletal systems of marine benthic invertebrates (e.g., Cattaert and Edwards, 2017; Hartenstein, 2017; Kristan, 2017), an electrical stimulus may have different effects on locomotion behaviour. To assess the potential impact on locomotion performance in benthic invertebrates, we studied the effects in six species: common starfish (Asterias rubens), serpent star (Ophiura ophiura), common whelk (Buccinum undatum), sea mouse (Aphrodita aculeata), common hermit crab (Pagurus bernhardus), and flying crab (Liocarcinus holsatus). These species represent four different phyla, inhabit areas trawled by pulse trawlers (e.g., Witbaard et al., 2013; ICES, 2018), and have been previously used as model species.

To measure the impact of electrical pulses on behaviour, we measured species-specific locomotion behaviour before and after electrical stimulation and we compare the results to those for a non-exposed control group. In addition, we studied the acute behaviour during electrical stimulation and the recovery from any acute responses thereafter. Speciesspecific locomotion behaviours were chosen that may indicate prolonged changes related to predation risk. These behaviours include righting reflexes and locomotion activity such as walking and burying. Righting reflexes have been used as overall health and stress indicators in echinoderms (Lawrence and Cowell, 1996; Canty et al., 2009), and as stress indicator in gastropods, where delayed righting duration may increase predation risk (Ramsay and Kaiser, 1998). Burying activity has been used as bioassay for predation risk in annelids (Schaum et al., 2013). In crustaceans, general activity scores have been used as indicators for predation-risk-related behaviour (Ejdung, 1998). By recording differences in righting duration and locomotion activity between control and exposure groups, we effectively detect responses to electrical stimulation. Particularly, increased righting duration and prolonged immobility after stimulation would be indicative of compromised survivability. Finally, we assessed animal survival at 14 days after the behavioural assessment to expand on previous experiments (Smaal and Brummelhuis, 2005; van Marlen et al., 2009; Soetaert et al., 2014, 2016).

\section{MATERIALS AND METHODS}

\section{Experimental Procedure}

Animals were acclimated to the laboratory housing at least two weeks prior to experimentation and were fed two-to-three times per week (Supplementary Material 1). The experimental procedure consisted of a pre-treatment measurement of speciesspecific behaviour, a stimulation period of $3 \mathrm{~s}$, with electrical pulses turned on (exposure group) or turned off (control group), a 30 s recovery period, followed by measuring 
post-treatment species-specific behaviour similar to the pretreatment measurement. Animals were transferred from the housing tank to the experimental setup while submerged in a transportation cup. The pre-treatment behavioural assessment started directly after placing the animal in the setup. To start the post-treatment measurements in a similar way, animals were also placed in the transportation cup after the $30 \mathrm{~s}$ recovery period.

Pre- and post-treatment measurements were adapted to the relevant behavioural repertoire of each species. An overview of the species-specific experimental procedure, including the number of animals, is provided in Table 1. Experiments were performed under well-controlled laboratory conditions in one of two identical setups, for one individual at the time. Waiting times between pre-treatment behavioural measurements, the treatment, and post-treatment measurements were minimised and similar in the control and exposure group. Animals were randomly assigned to the exposure or control group. After completing the behavioural measurements, wet mass and body length were measured (Supplementary Material 2) and the animals were transferred to the housing tanks to monitor survival for 14 days.

\section{Experimental Animals and Housing Facilities}

All animals were caught using short ( $\sim 20 \mathrm{~min}$ ) fishing hauls with a 4-metre beam trawl and collected by scientists of the Flanders Research Institute for Agriculture, Fisheries and Food (ILVO). Common starfish, serpent star, common hermit crab, and flying crab were collected off the Belgium coast. Common whelk and sea mouse were collected off the English coast. Animals without visible injuries were selected and transported to the ILVO laboratory facilities in Ostend (Belgium) within $3 \mathrm{~h}$ after docking.

Each species was housed separately in tanks containing aerated natural seawater in a closed circulation system. Water quality parameters were monitored daily, including ammonium, nitrite, and nitrate (MQuant) and dissolved oxygen concentration and saturation, temperature, salinity, and conductivity (YSI Pro2030). Ammonium levels were always below $0.5 \mathrm{mg} \mathrm{L}^{-1}$ and salinity varied between 33.0-34.3. Water was partially changed when nitrite or nitrate levels exceeded 0.05 and $25 \mathrm{mg} \mathrm{L}^{-1}$ respectively. Starfish and whelk were kept in a room with artificial lighting consisting of a $20 \mathrm{~W}$ white LED floodlight (Bailey) at a 12:12 L:D regime. The other species were kept in a room with natural lighting conditions (October-December). Within this period, water temperatures partially followed outside temperatures and varied between $12.6-16.4{ }^{\circ} \mathrm{C}$, as the areas were not climate controlled. However, measurements for each species were conducted in short periods, and measurements for the control and exposure groups were balanced, thus limiting a possible effect of temperature.

All animals were housed in tanks with calibrated sediment (0.2-0.5 mm grain size) to allow for natural burying behaviour (e.g., van Dam, 1940; Dyer et al., 1982). To minimise stress and damage resulting from agonistic behaviour (Lee and Seed, 1992; Ramsay et al., 1997), housing for hermit and flying crab was enriched with shelters, and crabs were transferred to individual containers one week prior to the experiment (same as used during survival monitoring; see below).

\section{Experimental Setup}

Each experimental setup (Figure 1A), consisted of a glass tank with a $5 \mathrm{~cm}$ layer of levelled, calibrated sediment and two, plate-shaped stainless-steel electrodes placed in the width of the tank at $43 \mathrm{~cm}$ apart, and $1 \mathrm{~cm}$ from the tank's bottom. The gaps between the electrodes and glass side walls were closed off with PVC sheets to prevent animals from leaving the measurement area. The plate-shaped electrodes created a homogeneous electric field, minimising exposure variability (Soetaert et al., 2014). Each day, the tanks were filled with water from the housing tanks of the animals that would be used that day. No filter was connected to the experimental tanks, but water was aerated after each individual measurement session. Water quality parameters, including temperature were monitored at the

TABLE 1 | Overview of species, number of animals per treatment group, and behavioural response measurement types per species. In addition to pre- and post-treatment response measurements, acute behavioural responses were scored during stimulation and in the following $30 \mathrm{~s}$ (not shown). In common starfish and serpent star, walking duration was measured directly after the fifth pre-treatment righting event (i.e., during treatment and extending in the post-treatment period),

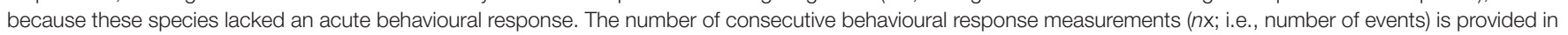
parentheses. After the behavioural response measurements, survival was monitored for 14 days (not shown).

\begin{tabular}{|c|c|c|c|c|c|c|c|c|c|}
\hline \multirow{3}{*}{$\begin{array}{l}\text { Species } \\
\text { Common starfish }\end{array}$} & \multicolumn{2}{|c|}{ Number of animals } & \multicolumn{7}{|c|}{ Behavioural responses } \\
\hline & \multirow{2}{*}{$\begin{array}{l}\text { Control } \\
44\end{array}$} & \multirow{2}{*}{$\begin{array}{l}\text { Exposure } \\
41\end{array}$} & \multicolumn{2}{|l|}{ Pre-treatment } & \multicolumn{2}{|c|}{ During treatment } & \multicolumn{2}{|c|}{ Post-treatment } & \multirow[b]{2}{*}{ Righting duration (5x) } \\
\hline & & & Righting duration (5x) & & $\leftarrow$ & Walking $d$ & uration (1x) & $\rightarrow$ & \\
\hline Serpent star & 21 & 21 & Righting duration (5x) & & $\leftarrow$ & Walking $d$ & uration (1x) & $\rightarrow$ & Righting duration $(5 x)$ \\
\hline Common whelk & 46 & 41 & Righting duration (1x) & $\begin{array}{l}\text { Duration until start of } \\
\text { burying or crawling } \\
\text { duration }(1 \mathrm{x})\end{array}$ & & & Righting $d$ & $n(1 x)$ & $\begin{array}{l}\text { Duration until start of } \\
\text { burying or crawling } \\
\text { duration }(1 \mathrm{x})\end{array}$ \\
\hline Sea mouse & 44 & 42 & Righting duration (1x) & $\begin{array}{l}\text { Duration until start of } \\
\text { burying or walking } \\
\text { duration }(1 x)\end{array}$ & & & Righting $d$ & $n(1 x)$ & $\begin{array}{l}\text { Duration until start of } \\
\text { burying or walking } \\
\text { duration }(1 x)\end{array}$ \\
\hline Common hermit crab & 43 & 43 & Righting duration (1x) & Locomotion activity $(1 x)$ & & & Righting $d$ & $n(1 x)$ & Locomotion activity (1x) \\
\hline Flying crab & 46 & 44 & Locomotion activity (1x & & & & Locomotic & ivity $(1)$ & \\
\hline
\end{tabular}




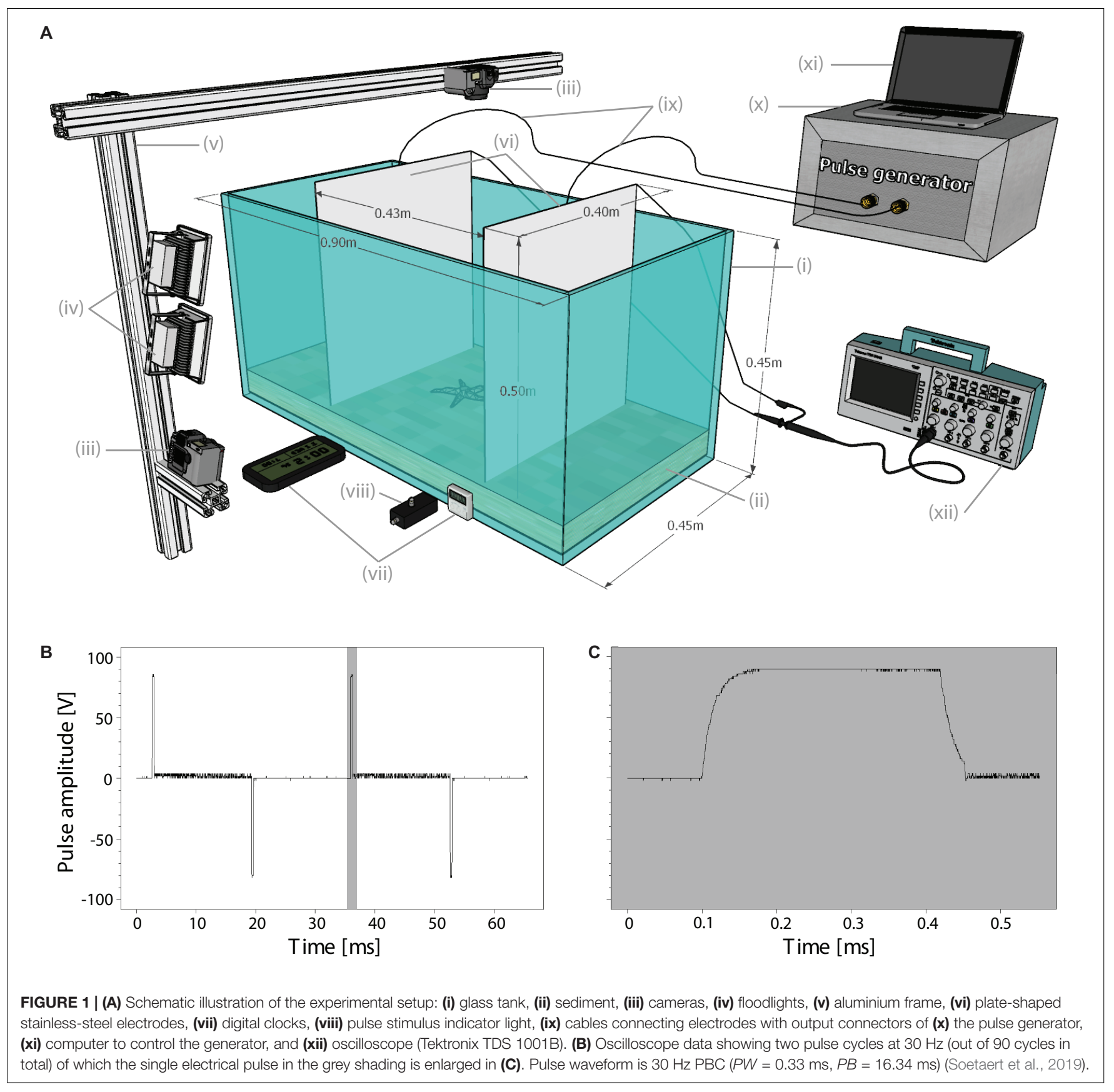

end of a measurement day and were found to remain stable and similar to the housing tanks.

We used two Casio Exilim Pro EX-F1 cameras $(1280 \times 720$ px, $30 \mathrm{fps}$ ) per tank to record the behaviour, one with a top view and one with a front view of the measurement area. Two floodlights above the front camera illuminated the setup. A transparent Plexiglas tray on top of the water prevented image distortions due to the water surface. Digital clocks (Technoline WS 8005 and Fisher Scientific) and a pulse stimulus indicator light were placed in view of the cameras for precise timing information. To minimise external disturbances, black curtains were placed around and above each experimental setup.
The electrical stimulus, generated by a high-power laboratory pulse generator (LPG, EPLG bvba, Belgium), consisted of rectangular-shaped Pulsed Bipolar Current (Soetaert et al., 2019) at a frequency of $30 \mathrm{~Hz}$ and pulse width of $0.33 \mathrm{~ms}$ (Figures 1B,C). These pulse parameters are similar to those used in a HFK PulseWing system targeting sole (Soetaert et al., 2014, 2019; pers. comm. Harmen Klein Woolthuis of HFK Engineering B.V.). We used a pulse exposure duration of $3 \mathrm{~s}$, which is about twice the duration animals would experience for commercial fishing gears with $4 \mathrm{~m}$ long electrode arrays (de Haan et al., 2016; Soetaert et al., 2019) towed at about 5 knots (van Marlen et al., 2014; Depestele et al., 2019; Poos et al., 2020; 
Rijnsdorp et al., 2020a). The electric field strength was set to $200 \mathrm{~V} \mathrm{~m}^{-1}\left(V_{\mathrm{pk}}\right.$ on electrodes $\left.=86 \mathrm{~V}\right)$, which equals the field strength at about $3 \mathrm{~cm}$ distance to commercial electrodes that are $40 \mathrm{~cm}$ apart (de Haan et al., 2016). A feedback system controlled the voltage, which was additionally monitored with an oscilloscope. At the start of a treatment, the animals were located upright in the middle of the experimental area, on top of the sediment. For species that needed repositioning, all animals were handled equally.

\section{Behavioural Responses}

For all species, except flying crab, species-specific behaviours included righting duration as relevant locomotion behaviour, where increased righting times may reveal negative effects of pulse stimulation. Single pre- and post-treatment rightings were measured to maximise the number of specimens per species, except for echinoderms, where we repeated rightings 5 times in accordance with variations in righting duration reported by Lawrence and Cowell (1996). Pilot measurements indicated low variability in righting duration for the other species. Because rightings sometimes take very long, or may be postponed indefinitely, one has to set a time limit to righting measurements. Time limits were species-specific and based on pilot measurements and, if available, literature data (Lawrence and Cowell, 1996; Davies et al., 1998; Ramsay and Kaiser, 1998; Canty et al., 2009). In all cases, the limits were at least 3 standard deviations above the mean righting duration. If an animal passed the time limit during the pre-treatment measurement (which was identical for exposure and control groups), we removed the animal from the experiment (numbers given in the results). These animals could not have shown increased post-treatment righting durations, and the same rule was applied for control and exposure groups. These exclusions were therefore unlikely to reduce a potential effect, and allowed us to increase the sample size and gain statistical power. Post-treatment time-outs were scored as missing data, and we performed an extended analysis to test the robustness of the statistical tests for different 'potential' durations (see results). Species-specific behaviours, such as walking/crawling and burying started after the pre- and post-treatment righting measurements. However, for starfish and serpent star that both lacked a response to stimulation, walking duration was measured starting immediately after the fifth righting event when the treatment was provided (i.e., only once), to increase sensitivity for detecting a potential effect.

To measure righting duration for starfish and serpent star, animals were picked up by hand from an upright orientation, with equal arm orientations, and were placed upside down on the sediment. Righting duration was defined as the time between the aboral surface touching the sediment and the ambulacra of all five arms in contact with the sediment (Canty et al., 2009). Starfish were given $17 \mathrm{~min}$ to right during each of the first five righting events. For starfish and serpent star walking duration was quantified by the time to move from the centre of the tank, directly after the fifth righting event, to the tank wall or electrode. We also scored when animals started burying in the sediment, in which case walking duration was a missing value.
For whelk and sea mouse, righting duration was measured once before and after treatment, in a procedure similar to that for the echinoderms. The animal was hand-released with the shell or dorsal side facing down and righting duration was measured from touching the sediment, until the complete foot or ventral side was in contact with the sediment (Fong et al., 2017). The time limits for rightings of whelk and sea mouse were set to $15 \mathrm{~min}$ and $10 \mathrm{~min}$ respectively. If animals passed the time limit in the post-treatment assessment they were manually righted for the subsequent behavioural assessment. To quantify locomotion behaviour for whelk and sea mouse we scored how many started burying and we measured (1) the time until the start of burying or (2) the time to reach a wall if they did not start to bury (crawling/walking duration). Complete burying duration could not be quantified as whelk and sea mouse often remained partly buried (van Dam, 1940; Himmelman and Hamel, 1993). We also scored when animals remained stationary on the sediment after righting, in which case the duration until the start of burying and crawling/walking duration was a missing value. In whelk, this occurred in one control and two exposure group specimens before treatment and two control and three exposure group animals after treatment. The post-treatment specimens that remained stationary include the three animals that were also stationary in the pre-treatment measurement.

For hermit crab we measured righting duration once before and once after treatment, in a procedure similar to that for whelk and sea mouse. Righting duration ended when all legs were in contact with the sediment and the shell was rotated to the normal position. We also quantified locomotion activity in a $500 \mathrm{~s}$ period after the righting reflex. Locomotion activity was quantified from the top camera footage, using an automated tracking procedure programmed in Python (Python Software Foundation, n.d.) in combination with OpenCV. The tracking algorithm provided a measure of the area changed from frame to frame, and of the number of objects corresponding to these changes (Supplementary Material 3). The former is more sensitive to whole-body movements, whereas the latter is also highly sensitive to movements of body extremities in the absence of wholebody movements. For flying crab, righting duration could not be measured and we only quantified locomotion activity, as described for the hermit crab.

Apart from crustacean locomotion activity, behavioural responses were scored in real-time. In case of doubt or missing values, the behaviours were scored from recorded videos.

\section{Survival}

After behavioural response measurements, animals were individually placed in custom-built containers and returned to their housing tanks (Supplementary Material 4). Survival monitoring was based on Kaiser and Spencer (1995) and performed daily on weekdays for 14 days. During survival monitoring, animals were not fed to emphasise possible vitality differences.

\section{Statistical Analyses}

The effect of treatment on righting duration, on walking/crawling duration, on the duration until the start of burying, and on 
locomotion activity (crabs) was analysed by fitting a linear mixed effect model by Restricted Maximum Likelihood. Each model included treatment (i.e., control and exposure), event (i.e., pre- and post-treatment measurements), as well as their interaction as fixed effects. Body mass and length were included as additional fixed effects to exclude a potential effect of body size differences between control and exposure groups on the measured behaviours. We include both body mass and length to account for changes in shape when animal size differs. Individual identity was included as a random effect to correct for pseudo-replication and for betweenindividual variation irrespective of fixed effects. Comparisons between the control and exposure group within each event were subsequently performed using a multiple comparison procedure. Because we used a species-specific design, models were applied to each species separately. Although body mass and length are collinear, this is irrelevant since we do not aim to disentangle these predictors, but merely wish to discount them in estimating the effect of electrical pulse treatment. Because we correct for body mass and length in the multiple comparison procedure, estimated treatment effects are independent of body size. Since walking duration for echinoderms was measured once, the potential effects were estimated in linear models (no random effects) using Maximum Likelihood. Similar to the linear mixed effect models, treatment, body mass and length were included as fixed effects. To meet the assumptions of normality and homoscedasticity, we performed a visual assessment for optimal data transformation. All species-specific behaviour data were ln-transformed, except for flying crab, where we applied a power transformation because in four instances a zero value was present in the dataset (animals remained stationary). The power parameter, lambda, was optimised for the area changed and for the number of objects separately $(0.265$ and 0.357, respectively). See Supplementary Material 5 for additional information on the statistical methods of the behavioural measurements.

The effect of electrical exposure on survival at 14 days after the behaviour measurements was assessed by fitting a generalized linear model by Maximum Likelihood and a logit link for the quasi-binomially distributed response, with treatment, species (i.e., common starfish, serpent star, common whelk, sea mouse, common hermit crab, and flying crab), and their interaction as fixed effects. Similarly to behavioural models, effects of body mass and length were taken into account. Speciesspecific comparisons of survival between the treatments were subsequently performed using a multiple comparison procedure. We used the quasi-binomial distribution because data were found to be underdispersed $(\varphi=0.39)$ when we used a binomial distribution. We compare results for the two distributions and further motivate the choice for the quasi-binomial distribution in Supplementary Material 6.

All statistical analyses were performed in $\mathrm{R}$ v3.6.1 ( $\mathrm{R}$ Core Team, 2019). Visual assessment of the optimal data transformation for the behavioural models was performed using the symbox function from the car package (Fox and Weisberg, 2019), mixed models were fitted using the lme 4 package (Bates et al., 2015), significance tests for the fixed effects were performed with lmerTest (Kuznetsova et al., 2017), and multiple comparison procedures were performed with multcomp (Hothorn et al., 2008). P-values were adjusted for multiple testing using the single-step method.

\section{RESULTS}

\section{Behavioural Responses}

Starfish and serpent star continued their normal behaviour during electrical stimulation, without signs of immobilisation or agitation. Starfish and serpent star either continued walking or burying, where starfish generally walked and serpent star more often buried. Pre-treatment righting durations for all starfish were $2.47 \pm 1.85$ min (mean \pm SD), with no clear trend, except for a slightly larger variability in the first righting (Figure 2A). Ten starfish (out of 95 animals in total) passed the $17 \mathrm{~min}$ time limit for righting in the pre-treatment period. Post-treatment righting times were similar to the pre-treatment times $(2.25 \pm 1.57 \mathrm{~min}$ and $2.31 \pm 1.17 \mathrm{~min}$ for control and exposure group respectively). Serpent star righted within several seconds with limited variation (Figure 2B). No significant differences were found between treatments in righting duration in any of the righting events, for starfish nor for serpent star (see Supplementary Material 5 for additional information on statistical output of the behavioural measurements). More exposed serpent star started walking instead of burying $(76.2 \%$ versus $38.1 \%$ for the control). Walking durations were neither significantly different between the control and exposed specimens for starfish $\left(t_{78}=0.233, p=0.816\right.$; Figure $\left.2 \mathrm{C}\right)$ nor for serpent star $\left(t_{20}=1.389, p=0.180\right.$; Figure 2D).

All whelk retracted, at least partly, in their shell during electrical stimulation. Responses immediately after electrical exposure were variable: one specimen remained retracted for the full $30 \mathrm{~s}, 14.6 \%$ exhibited escape type of movements by contorting the foot, but most animals showed limited locomotion activity. During or immediately after stimulation $63.4 \%$ of the animals ejected a white substance, presumably related to reproduction. The percentages of whelk, in control and exposure group respectively, that remained stationary $(60.9 \%$ and $63.4 \%$ ), crawled (37\% and $22 \%$ ), or buried $(2.2 \%$ and $4.9 \%)$ were similar. Pre-treatment righting durations for all whelk were $4.67 \pm 3.16 \mathrm{~min}$. Sixteen whelk (out of 103 animals in total) passed the $15 \mathrm{~min}$ time limit for righting in the pre-treatment period. Post-treatment righting durations were shorter, in both control $(2.81 \pm 1.63 \mathrm{~min})$ and exposed group $(2.74 \pm 2.40 \mathrm{~min})$ (Figure 3A), but differences between the control and exposed group were not significant $(z=-0.973$, $p=0.527)$. After electrical stimulation, the duration until the start of burying seemed lower for the exposed (29.5 $\pm 37.2 \mathrm{~s})$ than for the control specimens $(47.7 \pm 38.6 \mathrm{~s})$, but the difference was not significant ( $z=-1.701, p=0.162$; Figure 3B). Slightly more exposed whelk started crawling instead of burying $(51.2 \%$ versus $39.1 \%$ for the control). Crawlers reached the wall in $3.64 \pm 1.74 \mathrm{~min}$ (control) and $2.74 \pm 1.60 \mathrm{~min}$ (exposed group) 


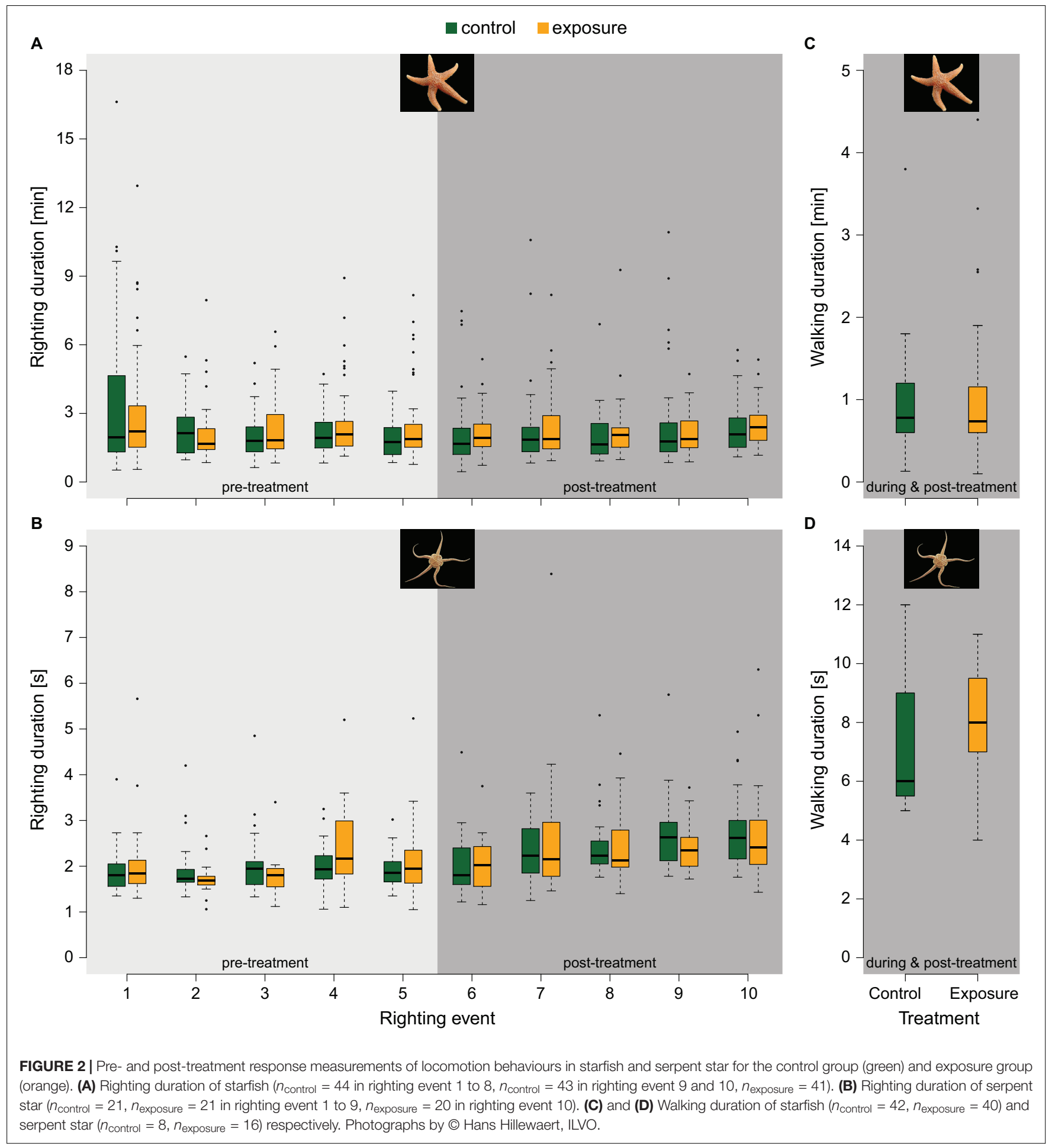

This difference was also not significant $(z=-1.685, p=0.170$; Figure 3C).

About half of the sea mouse (47.6\%) showed a squirming type of movement during stimulation. The remainder either kept walking $(2.4 \%)$ or burying $(11.9 \%)$, or showed no obvious response. In the $30 \mathrm{~s}$ after stimulation, no major differences between treatment groups were observed. Exposed sea mouse showed a slightly higher tendency to start walking (38.1\% versus $15.9 \%$ for the control group), and started burying less frequently (35.7\% versus 50\%). The other animals remained stationary (26.2\% for exposed and $34.1 \%$ for control animals). Pre-treatment righting times for all animals were $1.19 \pm 1.27 \mathrm{~min}$ 

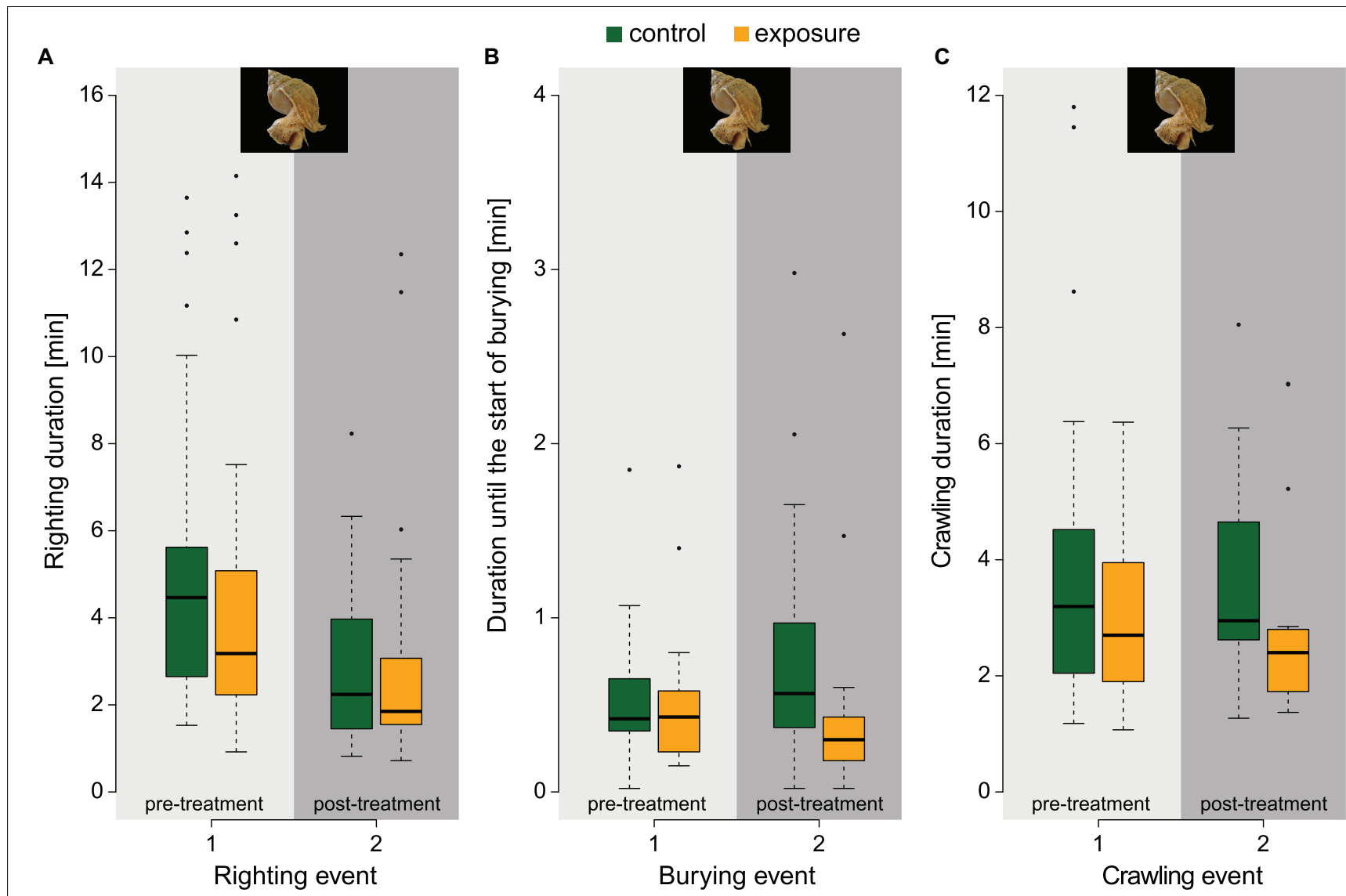

FIGURE 3 | Pre- and post-treatment response measurements of locomotion behaviours in whelk for the control group (green) and exposure group (orange).

(A) Righting duration of whelk ( $\left.n_{\text {pre\&post, control }}=46, n_{\text {pre\&post, exposure }}=41\right)$, whereafter each righting event, whelk could either start burying or crawl to the side of the setup, or remain stationary. (B) Duration until the start of burying of whelk ( $n_{\text {pre,control }}=25, n_{\text {pre, exposure }}=21, n_{\text {post,control }}=26, n_{\text {post,exposure }}=17$ ). (C) Crawling duration of whelk ( $\left.n_{\text {pre,control }}=20, n_{\text {pre, exposure }}=18, n_{\text {post, control }}=18, n_{\text {post,exposure }}=21\right)$. Photographs by $@$ Hans Hillewaert, ILVO.

(Figure 4A). Two sea mouse (out of 88 animals in total) passed the $10 \mathrm{~min}$ time limit for righting in the pre-treatment period. In addition, for 5 control and 8 exposed animals posttreatment values were missing due to passing the time limit in the post-treatment period. Because here extended righting times indicate a potential effect, these missing data potentially bias our results. To check this, we included them by assigning a value of $11 \mathrm{~min}$ (time limit plus 1) to the missing control animals and increasingly larger values for the exposed group. For values 10 times greater than the time limit, the effect of treatment was still non-significant $(z=2.132, p=0.062)$. This factor of 10 (i.e., $100 \mathrm{~min}$ ) corresponds to a highly unlikely value of 45 standard deviations (2.17 $\mathrm{min}$ ) above the mean (1.94 $\mathrm{min}$ ) of the measured righting durations. Relatively more sea mouse started to bury in the post-treatment period compared to the pre-treatment period, but this effect was similar for the control (79.5\% and $68.2 \%$ ) and exposure group (59.5\% and 54.8\%). Also, the duration until the start of burying (Figure 4B) was similar for the control (20.5 $\pm 17.2 \mathrm{~s})$ and for the exposed specimens (32.2 $\pm 33.9 \mathrm{~s})$ and did not differ significantly $(z=1.268$, $p=0.355)$. Animals that ensued walking after righting, took $57.7 \pm 29.7 \mathrm{~s}$ (control) and $73.0 \pm 46.8 \mathrm{~s}$ (exposed) to reach the wall (Figure 4C), which was not significantly different $(z=1.040, p=0.480)$.

Hermit crabs immediately retracted, mostly completely, into the shell upon stimulation. Immediately after stimulation behaviours of exposed and control animals were similar: The majority emerged within 30s and started walking or burying. Most hermit crabs righted within one minute in both treatment groups (Figure 5A). Post-treatment righting durations were significantly longer for the exposed group compared to the control group $(z=3.807, p<0.001)$. This was due to prolonged retraction durations, because hermit crabs showed variable emerging times. When we scored post-treatment righting duration starting at the moment of emerging from the shell (Figure 5B), the difference between the control (6.8 $\pm 13.0 \mathrm{~s})$ and exposed animals $(9.1 \pm 11.4 \mathrm{~s})$ was not significantly different $\left(t_{81}=1.663, p=0.100\right.$; estimated in a linear model using Maximum Likelihood, with treatment, body mass, and length as fixed effects; Supplementary Material 5). Hermit crabs displayed different behaviours during the locomotion activity period, including filtering sediment, walking, and burying. With locomotion activity quantified as the area changed, the exposed group showed significantly reduced activity compared 

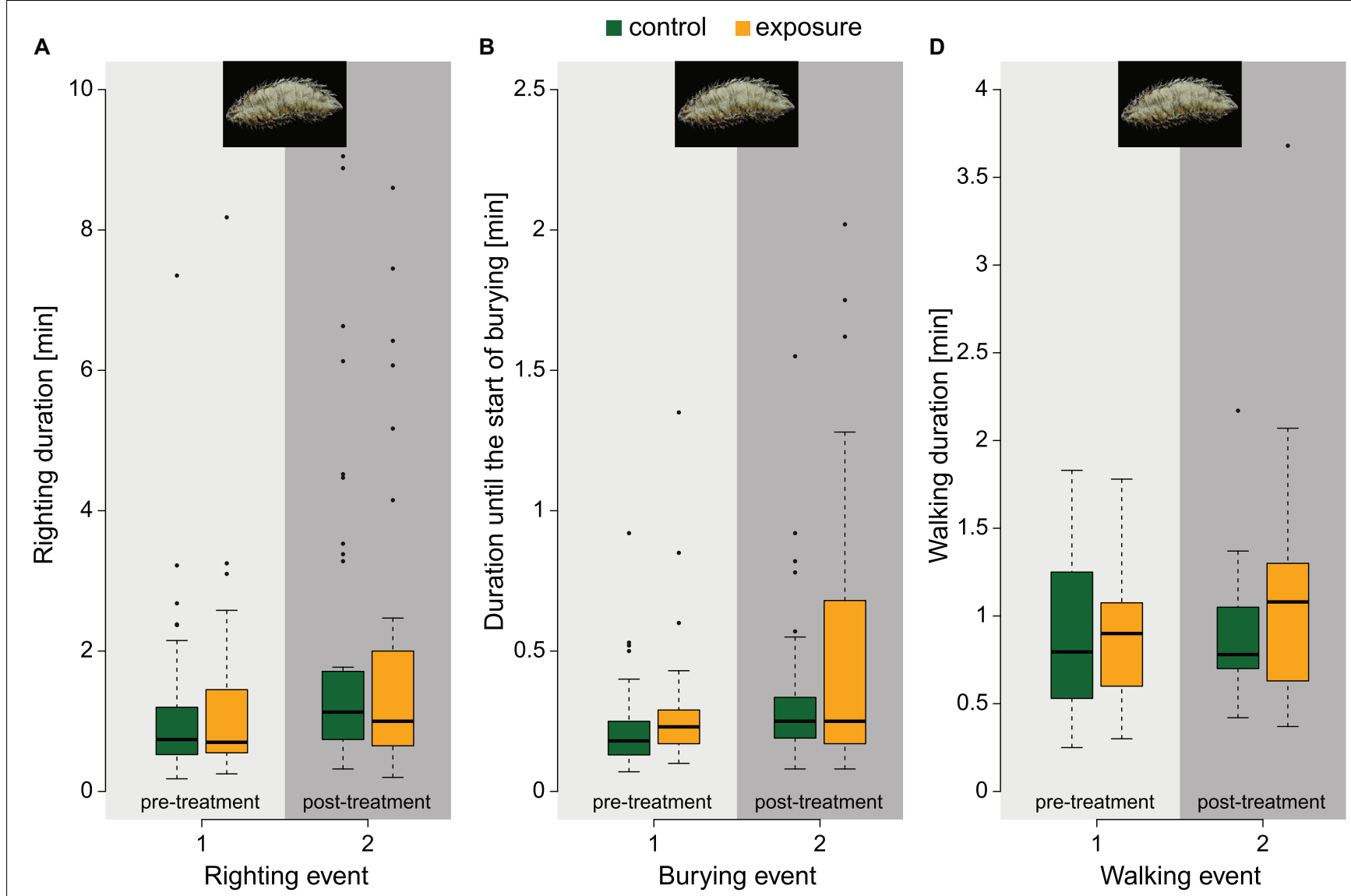

FIGURE 4 | Pre- and post-treatment response measurements of locomotion behaviours in sea mouse for the control group (green) and exposure group (orange). (A) Righting duration of sea mouse ( $n_{\text {pre,control }}=44, n_{\text {pre, exposure }}=42, n_{\text {post, control }}=39, n_{\text {post, exposure }}=34$ ), whereafter each righting event, sea mouse could either start burying or walk to the side of the setup. (B) Duration until the start of burying of sea mouse $\left(n_{\text {pre,control }}=30, n_{\text {pre,exposure }}=23, n_{\text {post,control }}=35\right.$,

$\left.n_{\text {post, exposure }}=25\right)$. (C) Walking duration of sea mouse $\left(n_{\text {pre, control }}=14, n_{\text {pre, exposure }}=19, n_{\text {post, control }}=9, n_{\text {post, exposure }}=17\right)$. Photographs by $(C$ Hans Hillewaert, ILVO.

to the control group in the post-treatment period $(z=-2.220$, $p=0.047$; Figure 5C). Yet, no significant differences were found when the locomotion activity was expressed as the number of moving objects $(z=-1.483, p=0.223$; Figure 5D). These measurements indicate that hermit crabs tend to continue normal activity of their extremities, but show reduced wholebody movements.

All flying crab withdrew their extremities during stimulation, and thereafter either swam, walked, or ran away immediately, whilst control animals remained stationary or walked slowly. None showed prolonged immobilisation. The exposed group, however, showed significant reductions of locomotion activity in the post-treatment period, both for activity quantified as the area changed ( $z=-2.353, p=0.036$; Figure $6 \mathbf{A})$ and as the number of moving objects $(z=-2.419, p=0.030$; Figure 6B). Area changed was reduced by a factor of 1.1 for control animals compared to a factor of 2 for exposed animals. Similarly, the number of moving parts was reduced by a factor of 1 for control animals compared to 1.7 for exposed animals. During the locomotion activity measurements animals in both the control and exposed group showed the full range of normal behaviours.

\section{Survival}

All starfish, whelk, and sea mouse survived the 14-days survival period. Serpent star survival of the control and exposure group was $86 \%$ and $81 \%$ respectively, which did not differ significantly $(z=-0.435, p=0.999)$. Hermit crab survival of the control and exposure group was 93\% and $91 \%$ respectively, which neither differed significantly $(z=-0.800, p=0.963)$. A significant difference in survival was found for flying crab, but survival was higher in the exposed group (86\%) than the control group (65\%) $(z=3.273, p=0.006)$. See Supplementary Material 6 for additional information on statistical output of the survival measurements.

\section{DISCUSSION}

Marine benthic invertebrates form a crucial link between primary producers and higher level consumers, hence disrupting invertebrate populations might affect benthic food webs (Covich et al., 2004; Heath, 2005; Sokołowski et al., 2012). To assess 
A

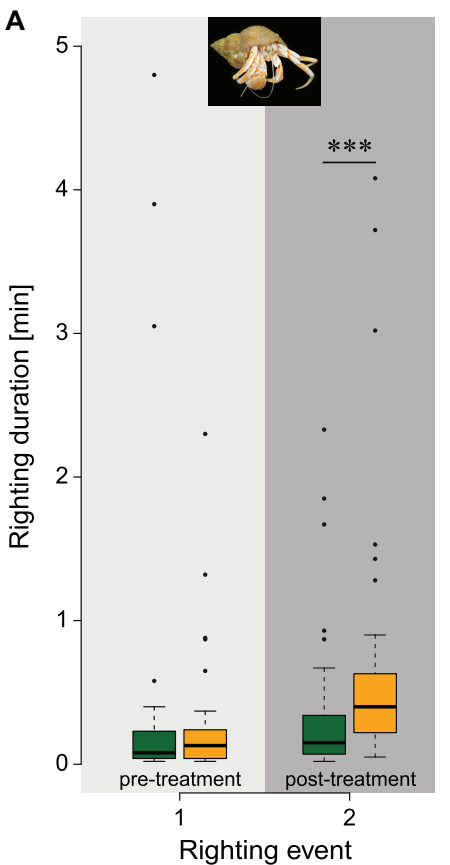

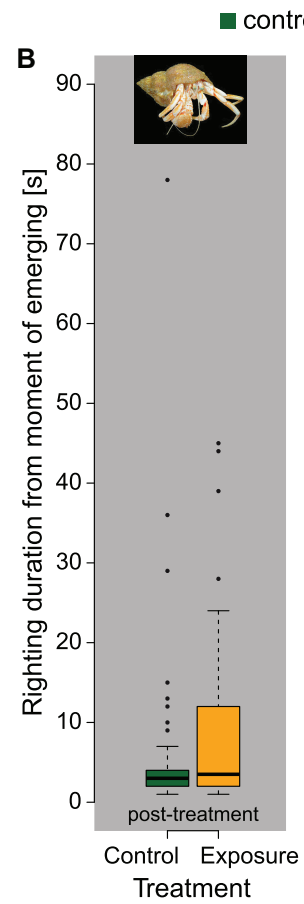
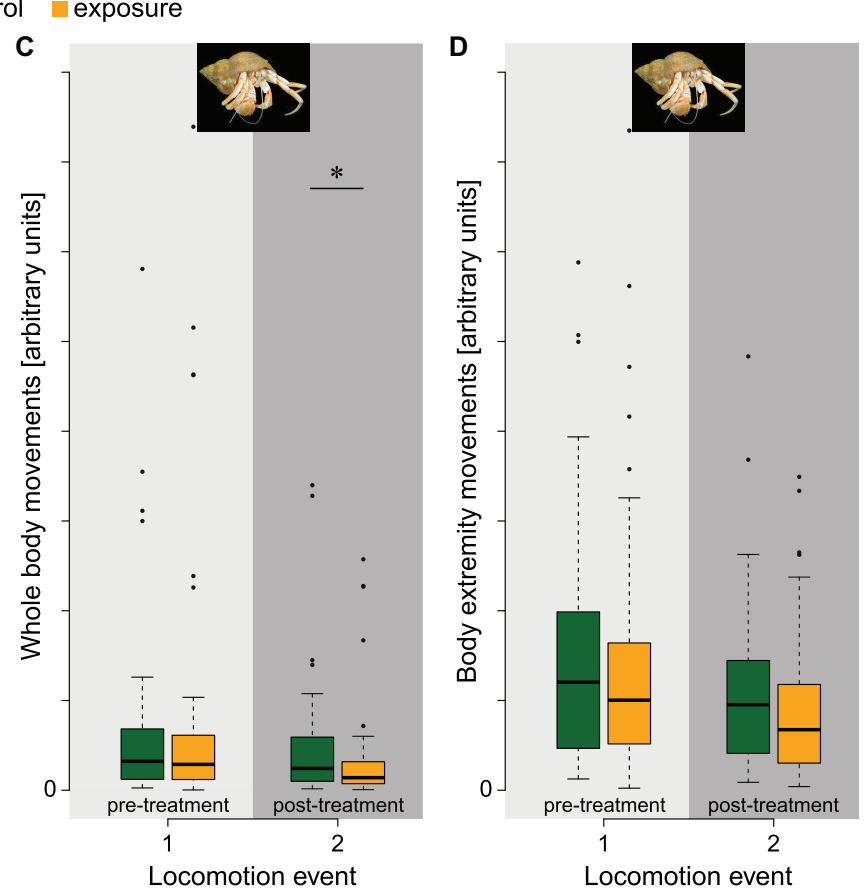

FIGURE 5 | Pre- and post-treatment measurements of locomotion behaviours in hermit crab for the control group (green) and exposed group (orange). (A) Righting duration of hermit crab as measured from moment of placement on the sediment ( $n_{\text {pre\&post,control }}=43, n_{\text {pre, exposure }}=43, n_{\text {post,exposure }}=42$ ). The exposed group had a significantly larger righting duration in the post-treatment assessment. (B) Post-treatment righting duration as measured from the moment of emerging from the shell $\left(n_{\text {control }}=43, n_{\text {exposure }}=42\right)$. After each righting event, locomotion activity was quantified with tracking software using $(\mathbf{C})$ the area changed as proxy for whole-body movements and (D) the number of objects as proxy for body extremity movements ( $n_{\text {pre\&post }}=43$ in both treatments). Animals in the exposure group had a significantly reduced whole-body movement but not in movements of the body extremities. Significance codes: ${ }^{* \star *} p \leq 0.001,0.01<{ }^{*} p \leq 0.05$. Photographs by (C) Hans Hillewaert, ILVO.

potential effects of electrical pulses on locomotion behaviour and survival of invertebrates, we studied six species with diverse neuromuscular and musculoskeletal systems. The selected species, from four phyla, occupy different niches and have different functions in benthic food webs in areas that are likely subjected to pulse trawling.

\section{Behavioural Responses}

We observed a wide range of acute responses during and immediately after electrical stimulation, ranging from no visible response in echinoderms, to immediate retractions in hermit crabs. Our observations correspond well to previous findings. Smaal and Brummelhuis (2005) and van Marlen et al. (2009) also reported absence of an acute response in echinoderms, including the same species, and Psammechinus miliaris and Ophiothrix fragilis. Other species showed different degrees of escape or defensive behaviours during and immediately after stimulation. In our study about half of the sea mouse squirmed during stimulation, which was not reported by Smaal and Brummelhuis (2005). In Alitta virens, another polychaete, a similar response pattern was observed, varying from no response (Smaal and Brummelhuis, 2005) to various intensities of squirming and jerky movements (van Marlen et al., 2009; Soetaert et al., 2014). Exposed sea mouse showed an increase in walking frequency directly after stimulation, indicating an increased escape response frequency, as sea mouse normally reside (partially) buried in the sediment (van Dam, 1940; Mettam, 1971). Hermit crab retracted and flying crab withdrew their extremities during electrical stimulation, but recovered after stimulation, as also found by Smaal and Brummelhuis (2005), followed by shelter and escape behaviour. These responses are similar to the tail flip responses in Crangon crangon and Palaemon spp., and stiffening in Carcinus maenas (Smaal and Brummelhuis, 2005; van Marlen et al., 2009; Soetaert et al., 2014, 2016). Our finding that invertebrates respond differently during stimulation, but that all resume their normal behavioural repertoire mostly within $30 \mathrm{~s}$ thus extends similar observations in previous studies.

In common whelk, we observed immediate retraction in their shell, similar to results of Smaal and Brummelhuis (2005) in the same species, and in another marine gastropod, Tritia reticulata. However, the observed foot contortions and ejection of a white substance have not previously been reported. Foot contortions are part of the marine gastropod escape response and similar to the behaviour when a potential predator is detected (Harvey et al., 1987; Thomas and Himmelman, 1988; Legault and Himmelman, 1993). Ejection of a white substance, presumably sperm, was observed in $63.4 \%$ of the specimens. Experiments were performed in autumn, in the reproductive season of the gonochoric whelk (Heude-Berthelin et al., 2011), and female animals were also observed depositing egg cases in the housing 


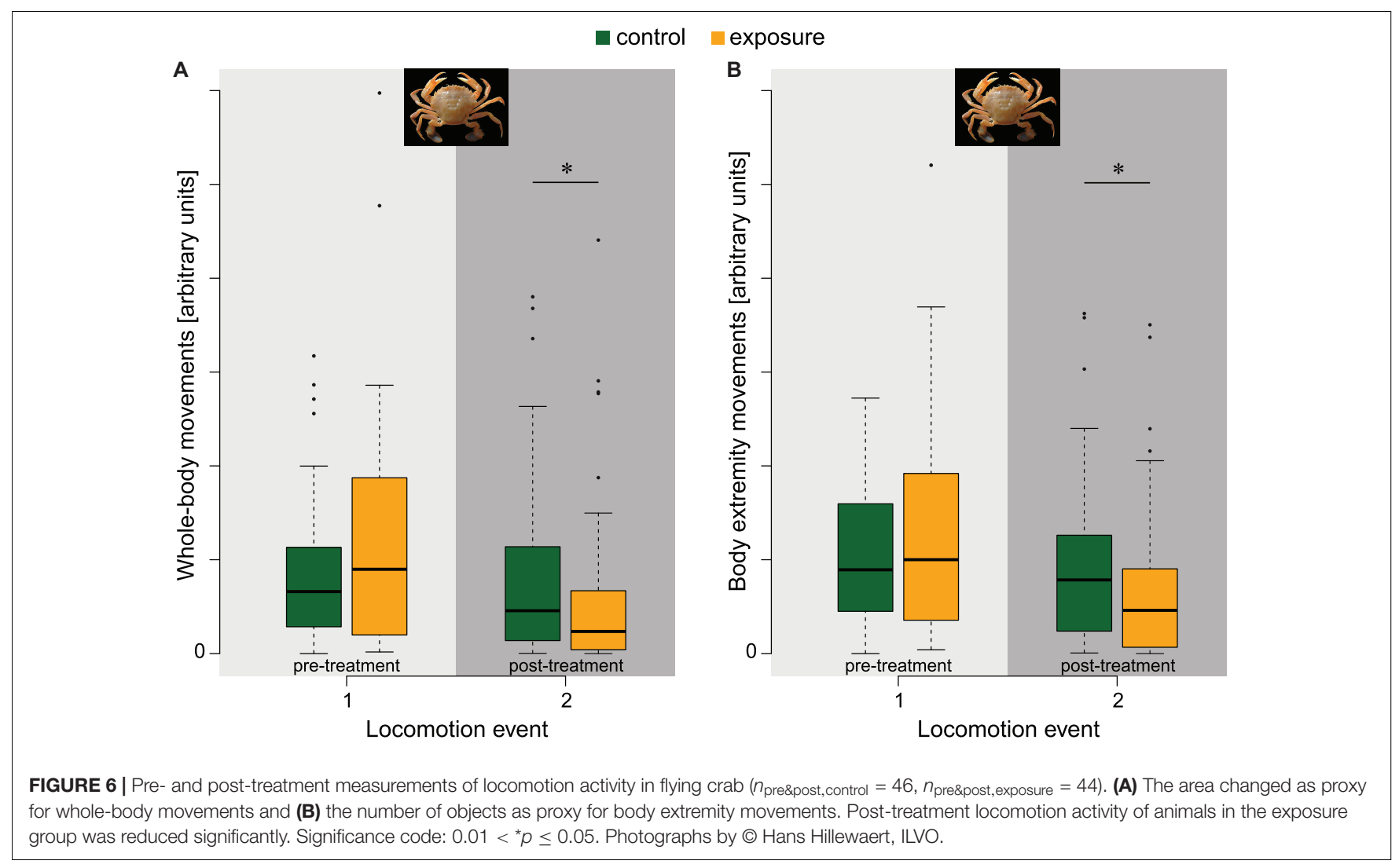

tank. It is unclear to what extent the presumed ejaculation of sperm would compromise whelk reproduction. Moreover, it raises the question whether the female reproductive system could be affected, which might affect egg-capsule depositions.

In all cases, animals resumed normal behavioural patterns within $30 \mathrm{~s}$ after stimulation. This, however, does not exclude longer lasting changes in locomotion performance that might compromise survival after a trawling event. To assess such additional effects, we performed quantitative comparisons of behaviours before and after electrical stimulation. These behaviours were chosen to be relevant for each specific species, such as righting reflexes, burying and walking/crawling activity. In particular, we were interested in changes that would increase the risk for predation after a trawling event, such as increased righting times or suppression of escape and shelter behaviours. In general, we found no indications for such effects. Righting duration and locomotion activity were not significantly affected by electrical stimulation in starfish, serpent star, whelk, and sea mouse. However, in serpent star and whelk we found shifts in the frequency of burying and walking/crawling, indicating that stimulation may induce escape behaviours (Himmelman and Hamel, 1993; Sköld, 1998). However, locomotion capacity appeared unaffected as the walking/crawling duration and duration until start of burying were not significantly different between exposed and control groups. Sea mouse, irrespective of treatment, displayed increased burying activity, indicating that their natural behaviour is not disrupted by stimulation. In hermit crab, post-treatment righting durations in the exposure group were significantly longer (Figure 5A). This, however, was due to increased retraction times, as the animals remained in their shell, resulting in almost complete protection (Kaiser and Spencer, 1995). Increased righting times thus indicate an increase of defensive behaviours that limits rather than increases risk for predation. For hermit crabs, we also found subtle changes in locomotion behaviour that indicate a reduction of wholebody displacements, while maintaining activity patterns related to e.g., feeding.

In flying crab, locomotion activity was significantly reduced, although the animals were obviously capable of immediate escape behaviour after stimulation. Predation risk can induce predation avoidance behaviour (Legault and Himmelman, 1993), by moving to safer habitats (Lima and Dill, 1990). Locomotion activity may reduce in response to predation risk (Lima and Dill, 1990), which decreases the probability of detection by the predator (Ejdung, 1998). Reduced activity of flying crab, due to increased burying activity and remaining stationary along the borders of the experimental area, could indicate that exposed specimens perceived the electrical stimulus as a threat, resulting in shelter behaviour. The shift in behaviour of flying crabs therefore does not necessarily compromise long-term survival.

\section{Survival}

We found no negative effect of electrical pulse stimulation on the 14-days survival. The lack of an effect was not due to high variability in survival; in half of the species we found no mortality at all. These findings corroborate with previous 
findings in starfish, serpent star, whelk, sea mouse, hermit crab, and flying crab (Smaal and Brummelhuis, 2005; van Marlen et al., 2009). For other species (i.e., Acanthocardia echinata, Cerastoderma edule, Ensis spp., Laevicardium crassum, Mytilus edulis, Spisula subtruncata, Tritia reticulata, Ophiothrix fragilis, Psammechinus miliaris, Carcinus maenas, Corystes cassivelaunus, Crangon crangon, Homarus americanus, Palaemon spp., and Alitta virens), variable survival rates after electrical exposure have been reported (Smaal and Brummelhuis, 2005; van Marlen et al., 2009; Soetaert et al., 2014, 2016). A significant negative effect on survival was found in some species, but only when different stimulus settings were combined in statistical modelling (van Marlen et al., 2009). Soetaert et al. (2016) found an effect on 14days survival, when stimulating repetitively over the course of multiple days, but only compared to one of the two controls. Our results suggest that for many species electrical exposure similar to that in commercial pulse fishing does not compromise survival.

\section{Limitations}

Even though our choice of species is limited, our results provide insight into the potential effects of electrical pulses on direct responses, post-treatment behaviour, as well as longterm survival. Obviously, extrapolation of our findings to other species and species groups should be done with caution. Moreover, because we focused on locomotion behaviour, effects on feed intake, growth, and reproduction remained outside the scope of the current study. Future studies could include a wider range of behaviours, and species with other body plans and infauna, as the electric field also penetrates the sediment (de Haan and Burggraaf, 2018).

We used undamaged specimens to minimise variation and therefore focused on effects of electrical stimulation in a healthy population. Injuries are also known to impact behaviour, predator-evasion-responses, and survival (Kaiser and Spencer, 1994, 1995; Ramsay and Kaiser, 1998; Bergman and van Santbrink, 2000; Depestele et al., 2014). Our measurements therefore do not include a potential combined effect of electrical stimulation and injuries. If these effects are of concern, one would need to conduct a much larger experiment to test the interaction of electrical stimulation and physical condition (e.g., injuries) of animals. Technically this is far more complicated and one should also consider that mechanical disturbance of pulse gears and beam trawl gears may be different (Depestele et al., 2016, 2019; Tiano et al., 2019). Bergman and Meesters (2020) found, for example, that direct mortality of benthic megafauna caused by pulse trawl gear was $43 \%$ less than a conventional beam trawl but the difference was not significant. Tiano et al. (2020) found no significant differences between the impact on smaller as well as deeper dwelling infauna by PulseWing rigged pulse trawlers and tickler-chain rigged beam trawlers.

To be able to finish a sufficiently large sample, we set a time limit to measurements that might last indefinitely. Time limits were well above the mean righting duration, hence only affect outliers. Animals that passed the limit in the pre-treatment measurements were removed from the experiment. By doing so we intended to increase the sensitivity for finding significant stimulation effects. Not only did it allow for a larger sample size, but animals that already passed the time limit in the pretreatment period could not have shown an increased duration after treatment. Setting time limits focuses the experiment on the average behaviour and may have occluded an effect for very slow animals, but it increased the statistical power and predictability for the bulk of the population, which is arguably more relevant. In our study, missing data were limited, and sensitivity analysis showed that they were highly unlikely to affect our conclusions.

In most cases, we did not find significant differences between the post-treatment control and exposure groups in the quantitative behavioural comparisons. These findings were not limited by sample size, which was sufficient to detect relevant treatment effects (see Supplementary Materials 5, 6). Small, potential differences below the statistical detection threshold, are considered irrelevant, given the time course of mechanical disturbance and sediment resuspension during in situ trawling events (Depestele et al., 2016, 2019; Tiano et al., 2019). These additional effects limit visibility, and thus vulnerability, beyond the potentially delayed behavioural response of exposed animals.

We subjected the animals to $200 \mathrm{~V} \mathrm{~m}^{-1}$ in a homogeneous electric field, which equals the electric field strength at about $3 \mathrm{~cm}$ next to a fishing gear electrode (de Haan et al., 2016; de Haan and Burggraaf, 2018). Inter-electrode distances for commercial gears are about $40 \mathrm{~cm}$, indicating that the majority of organisms is subjected to substantially weaker stimuli in commercial trawling. In addition, exposures were about a factor of two longer than an animal would experience in commercial trawling. In our experiments, animals were exposed only once to the electrical stimulus. We, therefore, cannot exclude that multiple, repetitive exposures would lead to other effects. Apart from a study by Soetaert et al. (2016), that found a limited impact of repetitive exposure on survival, but not on moulting, egg loss, and virus infection in Crangon crangon, effects of multiple exposures are unknown. However, the probability of repetitive exposure by commercial trawling is low (ICES, 2018). It therefore seems likely that our stimulus was substantially stronger than what the average population might experience.

Finally, many aspects play a role in assessing the impact of bottom trawling on the ecosystem, including catch efficiency, fishing effort and distribution, physical impact of the gear, seafloor and habitat characteristics, benthic community composition and sensitivity, and food web interactions (e.g., Queirós et al., 2006; Shephard et al., 2010; Pusceddu et al., 2014; van Denderen et al., 2014, 2015; Clark et al., 2016; Depestele et al., 2016; Eigaard et al., 2016; Sciberras et al., 2016; Rijnsdorp et al., 2018; Hiddink et al., 2019). Integrating these aspects into impact assessments of bottom trawling techniques is gaining international momentum (e.g., Eigaard et al., 2017; Hiddink et al., 2017, 2020; Sciberras et al., 2018; Mazor et al., 2020; Rijnsdorp et al., 2020b). Bottom fishing impact assessments, in turn, can support and facilitate fisheries management to reduce fishing effects on ecosystems (e.g., Pikitch et al., 2004; Crowder and Norse, 2008; Suuronen et al., 2012; Kaiser et al., 2016; McConnaughey et al., 2020). Our findings add to a scientific basis for weighing the advantages and disadvantages of electrical pulse fishing compared to other types of bottom fishing. 


\section{Conclusion}

Survival results nor behavioural results indicate a large detrimental effect of electrical pulses on invertebrates. We found species-specific differences in behavioural susceptibility of benthic marine invertebrates to electrical pulse stimulation. Direct effects were either absent (starfish and serpent star) or squirms (sea mouse), and retractions (whelk, hermit crab, and flying crab), potentially followed by increased escape or shelter behaviour. However, we never observed prolonged immobilisation or abnormal locomotion behaviour in any of the species and locomotion performance was not impaired. Indirect mortality, caused by increased predation susceptibility, is therefore expected to be minimal. Survival was not negatively affected in any species. Our findings provide a strong indication that concerns regarding survivability of invertebrates after electrical pulsing are not supported by scientific evidence.

\section{DATA AVAILABILITY STATEMENT}

The raw data supporting the conclusions of this article will be made available by the authors, without undue reservation.

\section{AUTHOR CONTRIBUTIONS}

All authors contributed to the conception and design of the study. PB and JR performed the measurements with live animals. ML programmed and executed the tracking procedure. $\mathrm{PB}$, JR, and ML collected the data, either by scoring real-time or from the video images. PB performed the statistical analyses and drafted the initial manuscript and figures, with contributions by MS, JR, and ML. All authors interpreted the data, discussed the results, contributed to the critical revision of the manuscript and figures, and approved the final version.

\section{FUNDING}

The authors declare that this study received funding from the Dutch Ministry of Agriculture, Nature and Food Quality via the Impact Assessment Pulsetrawl Fishery project

\section{REFERENCES}

Amoroso, R. O., Pitcher, C. R., Rijnsdorp, A. D., McConnaughey, R. A., Parma, A. M., Suuronen, P., et al. (2018). Bottom trawl fishing footprints on the world's continental shelves. Proc. Natl. Acad. Sci. U.S.A. 115, E10275-E10282. doi: 10.1073/pnas.1802379115

Bates, D., Mächler, M., Bolker, B. M., and Walker, S. C. (2015). Fitting linear mixed-effects models using lme4. J. Stat. Softw. 67, 1-48. doi: 10.18637/jss. v067.i01

Batsleer, J., Rijnsdorp, A. D., Hamon, K. G., van Overzee, H. M. J., and Poos, J. J. (2016). Mixed fisheries management: is the ban on discarding likely to promote more selective and fuel efficient fishing in the Dutch flatfish fishery? Fish. Res. 174, 118-128. doi: 10.1016/j.fishres.2015.09.006

Bayse, S. M., Herrmann, B., Lenoir, H., Depestele, J., Polet, H., Vanderperren, E., et al. (2016). Could a T90 mesh codend improve selectivity in the Belgian beam trawl fishery? Fish. Res. 174, 201-209. doi: 10.1016/j.fishres.2015.10.012 (contract number 1300021172). This research project is funded through the Dutch component of the European Maritime and Fisheries Fund of the European Union. The funding bodies were neither involved in the study design, collection, analysis, interpretation of data, and writing of this article nor in the decision to submit the article for publication.

\section{ACKNOWLEDGMENTS}

We thank the following people for their valuable contributions: crew and cruise participants of the RV Belgica and RV Simon Stevin for collecting experimental animals; Remco P.M. Pieters and Kas Koenraads for technical support; Mattias Van Opstal for technical assistance and advice; David Vuylsteke for technical support and animal caretaking; Laura Lemey and Rens Hensgens for assistance during monitoring of animal survival; Andres Hagmayer for advice and support with the statistical analyses; Hans Polet for enabling and facilitating experimentation at ILVO; Johan L. van Leeuwen for supervision and feedback on the manuscript. We thank the CARUS Aquatic Research Facility of Wageningen University for making available experimental equipment.

\section{SUPPLEMENTARY MATERIAL}

The Supplementary Material for this article can be found online at: https://www.frontiersin.org/articles/10.3389/fmars. 2020.592650/full\#supplementary-material

Supplementary Material 1 | Feeding of experimental animals.

Supplementary Material 2 | Body mass and length measurements.

Supplementary Material 3 | Example of activity measurements for crustaceans.

Supplementary Material 4 | The survival experiment.

Supplementary Material 5 | Statistical methods and output of behavioural measurements.

Supplementary Material 6 | Statistical methods and output of survival measurements.

Bergman, M. J. N., and Meesters, E. H. (2020). First indications for reduced mortality of non-target invertebrate benthic megafauna after pulse beam trawling. ICES J. Mar. Sci. 77, 846-857. doi: 10.1093/icesjms/fsz250

Bergman, M. J. N., and van Santbrink, J. W. (2000). Mortality in megafaunal benthic populations caused by trawl fisheries on the Dutch continental shelf in the North Sea in 1994. ICES J. Mar. Sci. 57, 1321-1331. doi: 10.1006/jmsc. 2000.0917

Canty, M. N., Hutchinson, T. H., Brown, R. J., Jones, M. B., and Jha, A. N. (2009). Linking genotoxic responses with cytotoxic and behavioural or physiological consequences: differential sensitivity of echinoderms (Asterias rubens) and marine molluscs (Mytilus edulis). Aquat. Toxicol. 94, 68-76. doi: 10.1016/j. aquatox.2009.06.001

Cashion, T., Al-Abdulrazzak, D., Belhabib, D., Derrick, B., Divovich, E., Moutopoulos, D. K., et al. (2018). Reconstructing global marine fishing gear use: catches and landed values by gear type and sector. Fish. Res. 206, 57-64. doi: 10.1016/j.fishres.2018.04.010 
Cattaert, D., and Edwards, D. H. (2017). "Control of locomotion in crustaceans," in The Oxford Handbook of Invertebrate Neurobiology, ed. J. H. Byrne (New York, NY: Oxford University Press). doi: 10.1093/oxfordhb/9780190456757.013.23

Chícharo, L., Chícharo, M., Gaspar, M., Regala, J., and Alves, F. (2002). Reburial time and indirect mortality of Spisula solida clams caused by dredging. Fish. Res. 59, 247-257. doi: 10.1016/S0165-7836(02)00012-7

Clark, M. R., Althaus, F., Schlacher, T. A., Williams, A., Bowden, D. A., and Rowden, A. A. (2016). The impacts of deep-sea fisheries on benthic communities: a review. ICES J. Mar. Sci. 73, i51-i69. doi: 10.1093/icesjms/ fsv123

Collie, J., Hiddink, J. G., van Kooten, T., Rijnsdorp, A. D., Kaiser, M. J., Jennings, S., et al. (2017). Indirect effects of bottom fishing on the productivity of marine fish. Fish Fish. 18, 619-637. doi: 10.1111/faf.12193

Collie, J. S., Hall, S. J., Kaiser, M. J., and Poiner, I. R. (2000). A quantitative analysis of fishing impacts on shelf-sea benthos. J. Anim. Ecol. 69, 785-798. doi: $10.1046 / j .1365-2656.2000 .00434 . x$

Covich, A. P., Austen, M. C., Bärlocher, F., Chauvet, E., Cardinale, B. J., Biles, C. L., et al. (2004). The role of biodiversity in the functioning of freshwater and marine benthic ecosystems. Bioscience 54, 767-775. doi: 10.1641/00063568(2004)054[0767:trobit]2.0.co;2

Crowder, L., and Norse, E. (2008). Essential ecological insights for marine ecosystem-based management and marine spatial planning. Mar. Policy 32, 772-778. doi: 10.1016/j.marpol.2008.03.012

Davies, I. M., Gillibrand, P. A., McHenery, J. G., and Rae, G. H. (1998). Environmental risk of ivermectin to sediment dwelling organisms. Aquaculture 163, 29-46. doi: 10.1016/S0044-8486(98)00211-7

de Groot, S. J. (1984). The impact of bottom trawling on benthic fauna of the North Sea. Ocean Manag. 9, 177-190. doi: 10.1016/0302-184X(84)90002-7

de Haan, D., and Burggraaf, D. (2018). Field Strength Profile in and Above the Seabed as Reference to Pulse Trawl Fishing on Dover Sole (Solea solea). Report number C022/18. IJmuiden: Wageningen Marine Research.

de Haan, D., Fosseidengen, J. E., Fjelldal, P. G., Burggraaf, D., and Rijnsdorp, A. D. (2016). Pulse trawl fishing: characteristics of the electrical stimulation and the effect on behaviour and injuries of Atlantic cod (Gadus morhua). ICES J. Mar. Sci. 73, 1557-1569. doi: 10.1093/icesjms/fsw018

Depestele, J., Degrendele, K., Esmaeili, M., Ivanović, A., Kröger, S., O’Neill, F. G., et al. (2019). Comparison of mechanical disturbance in soft sediments due to tickler-chain SumWing trawl vs. electro-fitted PulseWing trawl. ICES J. Mar. Sci. 76, 312-329. doi: 10.1093/icesjms/fsy124

Depestele, J., Desender, M., Benoît, H. P., Polet, H., and Vincx, M. (2014). Shortterm survival of discarded target fish and non-target invertebrate species in the "eurocutter" beam trawl fishery of the southern North Sea. Fish. Res. 154, 82-92. doi: 10.1016/j.fishres.2014.01.018

Depestele, J., Ivanović, A., Degrendele, K., Esmaeili, M., Polet, H., Roche, M., et al. (2016). Measuring and assessing the physical impact of beam trawling. ICES J. Mar. Sci. 73, i15-i26. doi: 10.1093/icesjms/fsv056

Dyer, M. F., Fry, W. G., Fry, P. D., and Cranmer, G. J. (1982). A series of North Sea benthos surveys with trawl and headline camera. J. Mar. Biol. Assoc. U K. 62, 297-313. doi: 10.1017/S0025315400057295

Eigaard, O. R., Bastardie, F., Breen, M., Dinesen, G. E., Hintzen, N. T., Laffargue, P., et al. (2016). Estimating seabed pressure from demersal trawls, seines, and dredges based on gear design and dimensions. ICES J. Mar. Sci. 73, i27-i43. doi: 10.1093/icesjms/fsv099

Eigaard, O. R., Bastardie, F., Hintzen, N. T., Buhl-Mortensen, L., Buhl-Mortensen, P. P., Catarino, R., et al. (2017). The footprint of bottom trawling in European waters: distribution, intensity, and seabed integrity. ICES J. Mar. Sci. 74, 847-865. doi: 10.1093/icesjms/fsw194

Ejdung, G. (1998). Behavioural responses to chemical cues of predation risk in a three-trophic-level Baltic Sea food chain. Mar. Ecol. Prog. Ser. 165, 137-144. doi: 10.3354/meps 165137

Evans, P. L., Kaiser, M. J., and Hughes, R. N. (1996). Behaviour and energetics of whelks, Buccinum undatum (L.), feeding on animals killed by beam trawling. J. Exp. Mar. Bio. Ecol. 197, 51-62. doi: 10.1016/0022-0981(95) 00144-1

Fong, P. P., Bury, T. B. S., Donovan, E. E., Lambert, O. J., Palmucci, J. R., and Adamczak, S. K. (2017). Exposure to SSRI-type antidepressants increases righting time in the marine snail Ilyanassa obsoleta. Environ. Sci. Pollut. Res. 24, 725-731. doi: 10.1007/s11356-016-7855-y
Fox, J., and Weisberg, S. (2019). An $\{R\}$ Companion to Applied Regression, 3rd Edn. London: SAGE Publications Ltd.

Haasnoot, T., Kraan, M., and Bush, S. R. (2016). Fishing gear transitions: lessons from the Dutch flatfish pulse trawl. ICES J. Mar. Sci. 73, 1235-1243. doi: 10. 1093/icesjms/fsw002

Hartenstein, V. (2017). "Development of the nervous system of invertebrates," in The Oxford Handbook of Invertebrate Neurobiology, ed. J. H. Byrne (New York, NY: Oxford University Press). doi: 10.1093/oxfordhb/9780190456757.013.3

Harvey, C., Garneau, F.-X., and Himmelman, J. (1987). Chemodetection of the predatory seastar Leptasterias polaris by the whelk Buccinum undatum. Mar. Ecol. Prog. Ser. 40, 79-86. doi: 10.3354/meps040079

Heath, M. R. (2005). Changes in the structure and function of the North Sea fish foodweb, 1973-2000, and the impacts of fishing and climate. ICES J. Mar. Sci. 62, 847-868. doi: 10.1016/j.icesjms.2005.01.023

Heude-Berthelin, C., Hégron-Macé, L., Legrand, V., Jouaux, A., Adeline, B., Mathieu, M., et al. (2011). Growth and reproduction of the common whelk Buccinum undatum in west Cotentin (Channel). France. Aquat. Living Resour. 24, 317-327. doi: 10.1051/alr/2011048

Hiddink, J. G., Jennings, S., Sciberras, M., Bolam, S. G., Cambiè, G., McConnaughey, R. A., et al. (2019). Assessing bottom trawling impacts based on the longevity of benthic invertebrates. J. Appl. Ecol. 56, 1075-1084. doi: 10.1111/1365-2664.13278

Hiddink, J. G., Jennings, S., Sciberras, M., Szostek, C. L., Hughes, K. M., Ellis, N., et al. (2017). Global analysis of depletion and recovery of seabed biota after bottom trawling disturbance. Proc. Natl. Acad. Sci. U.S.A. 114, 8301-8306. doi: 10.1073/pnas.1618858114

Hiddink, J. G., Johnson, A. F., Kingham, R., and Hinz, H. (2011). Could our fisheries be more productive? indirect negative effects of bottom trawl fisheries on fish condition. J. Appl. Ecol. 48, 1441-1449. doi: 10.1111/j.1365-2664.2011. 02036.x

Hiddink, J. G., Kaiser, M. J., Sciberras, M., McConnaughey, R. A., Mazor, T., Hilborn, R., et al. (2020). Selection of indicators for assessing and managing the impacts of bottom trawling on seabed habitats. J. Appl. Ecol. 57, 1199-1209. doi: $10.1111 / 1365-2664.13617$

Himmelman, J. H., and Hamel, J.-R. (1993). Diet, behaviour and reproduction of the whelk Buccinum undatum in the northern Gulf of St. Lawrence, eastern Canada. Mar. Biol. 116, 423-430. doi: 10.1007/BF00350059

Hothorn, T., Bretz, F., and Westfall, P. (2008). Simultaneous inference in general parametric models. Biometrical J. 50, 346-363. doi: 10.1002/bimj.200810425

ICES (2018). Report of the Working Group on Electric Trawling (WGELECTRA). ICES document CM 2018/EOSG: 10. Copenhagen: International Council for the Exploration of the Sea.

Kaiser, M. J., Clarke, K. R., Hinz, H., Austen, M. C. V., Somerfield, P. J., and Karakassis, I. (2006). Global analysis of response and recovery of benthic biota to fishing. Mar. Ecol. Prog. Ser. 311, 1-14. doi: 10.3354/meps311001

Kaiser, M. J., Collie, J. S., Hall, S. J., Jennings, S., and Poiner, I. R. (2002). Modification of marine habitats by trawling activities: prognosis and solutions. Fish Fish. 3, 114-136. doi: 10.1046/j.1467-2979.2002.00079.x

Kaiser, M. J., Hilborn, R., Jennings, S., Amaroso, R., Andersen, M., Balliet, K., et al. (2016). Prioritization of knowledge-needs to achieve best practices for bottom trawling in relation to seabed habitats. Fish Fish. 17, 637-663. doi: $10.1111 /$ faf. 12134

Kaiser, M. J., and Spencer, B. E. (1994). Fish scavenging behaviour in recently trawled areas. Mar. Ecol. Prog. Ser. 112, 41-49. doi: 10.3354/meps112041

Kaiser, M. J., and Spencer, B. E. (1995). Survival of by-catch from a beam trawl. Mar. Ecol. Prog. Ser. 126, 31-38. doi: 10.3354/meps126031

Kristan, W. (2017). "Control of locomotion in annelids," in The Oxford Handbook of Invertebrate Neurobiology, ed. J. H. Byrne (New York, NY: Oxford University Press). doi: 10.1093/oxfordhb/9780190456757.013.22

Kuznetsova, A., Brockhoff, P. B., and Christensen, R. H. B. (2017). lmerTest package: tests in linear mixed effects models. J. Stat. Softw. 82, 1-26. doi: 10. 18637 /jss.v082.i13

Lawrence, J. M., and Cowell, B. C. (1996). The righting response as an indication of stress in Stichaster striatus (Echinodermata, Asteroidea). Mar. Freshw. Behav. Physiol. 27, 239-248. doi: 10.1080/10236249609378969

Lee, S. Y., and Seed, R. (1992). Ecological implications of cheliped size in crabs: some data from Carcinus maenas and Liocarcinus holsatus. Mar. Ecol. Prog. Ser. 84, 151-160. doi: 10.3354/meps084151 
Legault, C., and Himmelman, J. H. (1993). Relation between escape behaviour of benthic marine invertebrates and the risk of predation. J. Exp. Mar. Bio. Ecol. 170, 55-74. doi: 10.1016/0022-0981(93)90129-C

Lescrauwaet, A. K., Torreele, E., Vincx, M., Polet, H., and Mees, J. (2013). Invisible catch: a century of bycatch and unreported removals in sea fisheries, Belgium 1929-2010. Fish. Res. 147, 161-174. doi: 10.1016/j.fishres.2013. 05.007

Lima, S. L., and Dill, L. M. (1990). Behavioral decisions made under the risk of predation: a review and prospectus. Can. J. Zool. 68, 619-640. doi: 10.1139/ z $90-092$

Lindeboom, H. J., and de Groot, S. J. (1998). Impact II: The Effects of Different Types of Fisheries on the North Sea and Irish Sea Benthic Ecosystems. NIOZ-Rapport 1998-1. Den Burg: Netherlands Insitute for Sea Research; RIVO-DLO report C003/98. IJmuiden: Netherlands Institute for Fisheries Research.

Mazor, T., Pitcher, C. R., Rochester, W., Kaiser, M. J., Hiddink, J. G., Jennings, S., et al. (2020). Trawl fishing impacts on the status of seabed fauna in diverse regions of the globe. Fish Fish. 1-15. doi: 10.1111/faf.12506

McConnaughey, R. A., Hiddink, J. G., Jennings, S., Pitcher, C. R., Kaiser, M. J., Suuronen, P., et al. (2020). Choosing best practices for managing impacts of trawl fishing on seabed habitats and biota. Fish Fish. 21, 319-337. doi: 10.1111/ faf. 12431

Mettam, C. (1971). Functional design and evolution of the polychaete Aphrodite aculeata. J. Zool. 163, 489-514. doi: 10.1111/j.1469-7998.1971.tb04546.x

Murray, F., Copland, P., Boulcott, P., Robertson, M., and Bailey, N. (2016). Impacts of electrofishing for razor clams (Ensis spp.) on benthic fauna. Fish. Res. 174, 40-46. doi: 10.1016/j.fishres.2015.08.028

Paschen, M., Richter, U., and Köpnick, W. (2000). Trawl Penetration in the Seabed (TRAPESE). Final report EC-Study, Contract No. 96-006. Rostock: Universität Rostock, Fachbereich Maschinenbau und Schiffstechnik, Institut für Maritime Systeme und Strömungstechnik.

Pikitch, E. K., Santora, C., Babcock, E. A., Bakun, A., Bonfil, R., Conover, D. O., et al. (2004). Ecoystem-based fishery management. Science 305, 346-347. doi: $10.1126 /$ science. 1098222

Poos, J. J., Turenhout, M. N. J., Oostenbrugge, H. A. E., van, and Rijnsdorp, A. D. (2013). Adaptive response of beam trawl fishers to rising fuel cost. ICES J. Mar. Sci. 70, 675-684. doi: 10.1093/icesjms/fss196

Poos, J., Hintzen, N. T., Rijssel, J. C., Van, and Rijnsdorp, A. D. (2020). Efficiency changes in bottom trawling for flatfish species as a result of the replacement of mechanical stimulation by electric stimulation. ICES J. Mar. Sci. 77, 2635-2645. doi: 10.1093/icesjms/fsaa126

Pusceddu, A., Bianchelli, S., Martín, J., Puig, P., Palanques, A., Masqué, P., et al. (2014). Chronic and intensive bottom trawling impairs deep-sea biodiversity and ecosystem functioning. Proc. Natl. Acad. Sci. U.S.A. 111, 8861-8866. doi: 10.1073/pnas.1405454111

Queirós, A. M., Hiddink, J. G., Kaiser, M. J., and Hinz, H. (2006). Effects of chronic bottom trawling disturbance on benthic biomass, production and size spectra in different habitats. J. Exp. Mar. Bio. Ecol. 335, 91-103. doi: 10.1016/j.jembe. 2006.03.001

Quirijns, F. J., Steins, N. A., Steenbergen, J., and Rijnsdorp, A. D. (2018). Recommendations for Additional Research into Pulse-trawl Fisheries: Based on an Inventory of Stakeholder Concerns. Report C106/18. IJmuiden: Wageningen Marine Research. doi: 10.18174/466766

R Core Team (2019). R: A Language and Environment for Statistical Computing. Vienna: R Foundation for Statistical Computing.

Ramsay, K., and Kaiser, M. J. (1998). Demersal fishing disturbance increases predation risk for whelks (Buccinum undatum L.). J. Sea Res. 39, 299-304. doi: 10.1016/S1385-1101(98)00005-7

Ramsay, K., Kaiser, M. J., and Hughes, R. N. (1997). A field study of intraspecific competition for food in hermit crabs (Pagurus bernhardus). Estuar. Coast. Shelf Sci. 44, 213-220. doi: 10.1006/ecss.1996.0213

Rijnsdorp, A. D., Bolam, S. G., Garcia, C., Hiddink, J. G., Hintzen, N. T., van Denderen, P. D., et al. (2018). Estimating sensitivity of seabed habitats to disturbance by bottom trawling based on the longevity of benthic fauna. Ecol. Appl. 28, 1302-1312. doi: 10.1002/eap.1731

Rijnsdorp, A. D., Depestele, J., Eigaard, O. R., Hintzen, N. T., Ivanovic, A., Molenaar, P., et al. (2020a). Mitigating seafloor disturbance of bottom trawl fisheries for North Sea sole Solea solea by replacing mechanical with electrical stimulation. PLOS ONE 15:e0228528. doi: 10.1371/journal.pone.0228528
Rijnsdorp, A. D., Hiddink, J. G., van Denderen, P. D., Hintzen, N. T., Eigaard, O. R., Valanko, S., et al. (2020b). Different bottom trawl fisheries have a differential impact on the status of the North Sea seafloor habitats. ICES J. Mar. Sci. 77, 1772-1786. doi: 10.1093/icesjms/fsaa050

Rijnsdorp, A. D., Poos, J. J., Quirijns, F. J., HilleRisLambers, R., De Wilde, J. W., and Den Heijer, W. M. (2008). The arms race between fishers. J. Sea Res. 60, 126-138. doi: 10.1016/j.seares.2008.03.003

Schaum, C. E., Batty, R., and Last, K. S. (2013). Smelling danger - Alarm cue responses in the polychaete Nereis (Hediste) diversicolor (Müller, 1776) to potential fish predation. PLOS ONE 8:e77431. doi: 10.1371/journal.pone. 0077431

Sciberras, M., Hiddink, J. G., Jennings, S., Szostek, C. L., Hughes, K. M., Kneafsey, B., et al. (2018). Response of benthic fauna to experimental bottom fishing: a global meta-analysis. Fish Fish. 19, 698-715. doi: 10.1111/faf.12283

Sciberras, M., Parker, R., Powell, C., Robertson, C., Kröger, S., Bolam, S., et al. (2016). Impacts of bottom fishing on the sediment infaunal community and biogeochemistry of cohesive and non-cohesive sediments. Limnol. Oceanogr. 61, 2076-2089. doi: 10.1002/lno.10354

Shephard, S., Brophy, D., and Reid, D. G. (2010). Can bottom trawling indirectly diminish carrying capacity in a marine ecosystem? Mar. Biol. 157, 2375-2381. doi: 10.1007/s00227-010-1502-9

Sköld, M. (1998). Escape responses in four epibenthic brittle stars (Ophiuroidea: Echinodermata). Ophelia 49, 163-179. doi: 10.1080/00785326.1998.1040 9380

Smaal, A. C., and Brummelhuis, E. (2005). Onderzoek Naar Mogelijke Effecten van de Pulskor op Bodemdieren. RIVO rapport, nummer: C089/05. IJmuiden: Nederlands Instituut voor Visserij Onderzoek.

Soetaert, M., Boute, P. G., and Beaumont, W. R. C. (2019). Guidelines for defining the use of electricity in marine electrotrawling. ICES J. Mar. Sci. 76, 1994-2007. doi: $10.1093 /$ icesjms/fsz122

Soetaert, M., Chiers, K., Duchateau, L., Polet, H., Verschueren, B., and Decostere, A. (2014). Determining the safety range of electrical pulses for two benthic invertebrates: brown shrimp (Crangon crangon L.) and ragworm (Alitta virens S.). ICES J. Mar. Sci. 72, 973-980. doi: 10.1093/icesjms/fsu176

Soetaert, M., Decostere, A., Polet, H., Verschueren, B., and Chiers, K. (2015). Electrotrawling: a promising alternative fishing technique warranting further exploration. Fish Fish. 16, 104-124. doi: 10.1111/faf.12047

Soetaert, M., Verschueren, B., Chiers, K., Duchateau, L., Polet, H., and Decostere, A. (2016). Laboratory study on the impact of repetitive electrical and mechanical stimulation on brown shrimp Crangon crangon. Mar. Coast. Fish. Dyn. Manag. Ecosyst. Sci. 8, 404-411. doi: 10.1080/19425120.2016.118 0333

Sokołowski, A., Wołowicz, M., Asmus, H., Asmus, R., Carlier, A., Gasiunaité, Z., et al. (2012). Is benthic food web structure related to diversity of marine macrobenthic communities? Estuar. Coast. Shelf Sci. 108, 76-86. doi: 10.1016/j. ecss.2011.11.011

Suuronen, P., Chopin, F., Glass, C., Løkkeborg, S., Matsushita, Y., Queirolo, D., et al. (2012). Low impact and fuel efficient fishing - Looking beyond the horizon. Fish. Res. 11, 135-146. doi: 10.1016/j.fishres.2011.12.009

Thomas, M. L. H., and Himmelman, J. H. (1988). Influence of predation on shell morphology of Buccinum undatum L. on Atlantic coast of Canada. J. Exp. Mar. Bio. Ecol. 115, 221-236. doi: 10.1016/0022-0981(88)90156-6

Tiano, J. C., van der Reijden, K. J., O’Flynn, S., Beauchard, O., van der Ree, S., van der Wees, J., et al. (2020). Experimental bottom trawling finds resilience in large-bodied infauna but vulnerability for epifauna and juveniles in the Frisian Front. Mar. Environ. Res. 159:104964. doi: 10.1016/j.marenvres.2020.104964

Tiano, J. C., Witbaard, R., Bergman, M. J. N., van Rijswijk, P., Tramper, A., van Oevelen, D., et al. (2019). Acute impacts of bottom trawl gears on benthic metabolism and nutrient cycling. ICES J. Mar. Sci. 76, 1917-1930. doi: 10.1093/ icesjms/fsz060

van Dam, L. (1940). On the mechanism of ventilation in Aphrodite aculeata. J. Exp. Biol. 17, 1-7.

van Denderen, P. D., Hintzen, N. T., Rijnsdorp, A. D., Ruardij, P., and van Kooten, T. (2014). Habitat-specific effects of fishing disturbance on benthic species richness in marine soft sediments. Ecosystems 17, 1216-1226. doi: 10.1007/ s10021-014-9789-x

van Denderen, P. D., Hintzen, N. T., van Kooten, T., and Rijnsdorp, A. D. (2015). Temporal aggregation of bottom trawling and its implication for the impact 
on the benthic ecosystem. ICES J. Mar. Sci. 72, 952-961. doi: 10.1093/icesjms/ fsu 183

van Denderen, P. D., van Kooten, T., and Rijnsdorp, A. D. (2013). When does fishing lead to more fish? community consequences of bottom trawl fisheries in demersal food webs. Proc. R. Soc. B Biol. Sci. 280:20131883. doi: 10.1098/rspb. 2013.1883

van der Reijden, K. J., Hintzen, N. T., Govers, L. L., Rijnsdorp, A. D., and Olff, H. (2018). North Sea demersal fisheries prefer specific benthic habitats. PLOS ONE 13:e0208338. doi: 10.1371/journal.pone.0208338

van der Reijden, K. J., Molenaar, P., Chen, C., Uhlmann, S. S., Goudswaard, P. C., and Van Marlen, B. (2017). Survival of undersized plaice (Pleuronectes platessa), sole (Solea solea), and dab (Limanda limanda) in North Sea pulse-trawl fisheries. ICES J. Mar. Sci. 74, 1672-1680. doi: 10.1093/icesjms/ fsx019

van Marlen, B., de Haan, D., van Gool, A., and Burggraaf, D. (2009). The Effect of Pulse Stimulation on Marine biota - Research in Relation to ICES advice Progress Report on the Effects on Benthic Invertebrates. Report number C103/09. IJmuiden: Institute for Marine Resources \& Ecosystem Studies.

van Marlen, B., Wiegerinck, J. A. M., van Os-Koomen, E., and van Barneveld, E. (2014). Catch comparison of flatfish pulse trawls and a tickler chain beam trawl. Fish. Res. 151, 57-69. doi: 10.1016/j.fishres.2013.11.007
Watson, R., Revenga, C., and Kura, Y. (2006). Fishing gear associated with global marine catches: II. Trends in trawling and dredging. Fish. Res. 79, 103-111. doi: 10.1016/j.fishres.2006.01.013

Watson, R. A., and Tidd, A. (2018). Mapping nearly a century and a half of global marine fishing: 1869-2015. Mar. Policy 93, 171-177. doi: 10.1016/j.marpol. 2018.04.023

Witbaard, R., Lavaleye, M. S. S., Duineveld, G. C. A., and Bergman, M. J. N. (2013). Atlas of the Megabenthos (incl. small fish) on the Dutch Continental Shelf of the North Sea. NIOZ Report 2013-4. Den Burg: Royal Netherlands Institute for Sea Research.

Conflict of Interest: The authors declare that the research was conducted in the absence of any commercial or financial relationships that could be construed as a potential conflict of interest.

Copyright (c) 2021 Boute, Soetaert, Reid Navarro and Lankheet. This is an open-access article distributed under the terms of the Creative Commons Attribution License (CC BY). The use, distribution or reproduction in other forums is permitted, provided the original author(s) and the copyright owner(s) are credited and that the original publication in this journal is cited, in accordance with accepted academic practice. No use, distribution or reproduction is permitted which does not comply with these terms. 